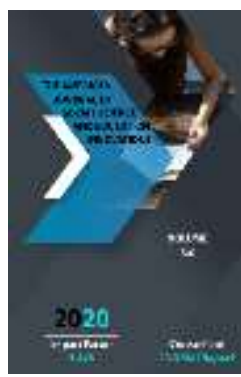

\title{
Journey From Central Asia To Mecca In The 19th Century: Roads And Conditions (Based On Muntahab Ut-Tawarikh)
}

\author{
Guldona Mamanovna Tanieva \\ Candidate Of History Sciences Senior Researcher At The Institute Of History of The Academy \\ Of Sciences Of The Republic Of Uzbekistan
}

\begin{abstract}
Journal Website: http://usajournalshub.c om/index,php/tajssei

Copyright: Original content from this work may be used under the terms of the creative commons attributes 4.0 licence.
\end{abstract}

\section{ABSTRACT}

It is known that in the XVI-early XX centuries there were three main routes from Central Asia to Mecca - the northern route through the territory of the Russian Empire, the southern route through India and the central route through Iran. It is through these routes that a number of works dedicated to the memories of the pilgrimage by some pilgrims who have made the pilgrimage have come down to us. They contain very valuable information about the history of the pilgrimages of the peoples of Central Asia, the ways of pilgrimage and the conditions in them.

\section{KEYWORDS}

Osaf ud-Dawla (Governor-General of Khurasan Province), Mutahab at tavarikh, Muhammadhakimkhan, butcher's steppe.

\section{INTRODUCTION}

One of such works is "Mutahab at tavarikh" by Muhammadhakimkhan Tora, which stands out among other works in the genre of travelogues created in the XIX century. The work is based on the author's impressions and memories of the pilgrimage. Muhammadhakimkhan Tora was born in 1802-1803 and was the grandson of Norbutabi (1770-1778), the governor of
Kokand. He writes that he was one of the many influential people and intellectuals who were persecuted by Muhammadalikhan (1822-1842) when he came to power in 1822 , Sh. Vahidov in the introductory part of the work. Due to this situation, Muhammadhakim Khan Tora was forced to embark on a long, arduous pilgrimage. B. Akhmedov also briefly dwells on 
this in his work. He wrote that Muhammadhakim Khan Tora, who had been appointed by Muhammadalikhan as the governor of Namangan, Turakurgan and Kasan, would soon be persecuted and sent on pilgrimage. This information suggests that pilgrimages were a means by the rulers of the Central Asian khanates to expel certain individuals from the country. There is a lot of evidence for this in historical works written in the XVI-XIX centuries. But it should be borne in mind that the data in historical sources show that pilgrimages were also a factor in saving their lives for some influential people who were under political pressure.

\section{THE MAIN RESULTS AND FINDINGS}

Thus, Muhammadhakim Khan Tora made a long pilgrimage during 1823-1828, and the memories of this journey form the basis for the writing of the above work based on his memories. The work was completed in 1843 and reprinted by the author in 10 more copies. It was written in Persian and 12 copies of it have been identified in science. They are kept in the manuscript collections of Uzbekistan, Tajikistan and Russia. This work was published in 1983 and 1985 in Dushanbe by A. Mukhtorov, in 2006 in Tokyo by Y. Kawahara and K. Hanida and this work is widely studied by Khurshut from the point of view of source studies. There is also an abbreviated version in Uzbek, which was published in 1964 by Fan Publishing House under the title "Memories", and in 2010 the Persian version was translated into Uzbek by Sh. Vahidov.

The work contains very valuable and accurate information about the history of the pilgrimage of the people of Central Asia. Of particular importance in it are information such as the direction of the pilgrimage routes from Central Asia to Mecca, the category of pilgrims, the difficulties of the journey. In particular, the play details the route of the northern pilgrimage route through Russia.

Kokand-Shamay (Semipalptinsk) -Omsk-IrbitTroitsk-Orenburg-Astrakhan-Hanifa (Anapa) Onaduli (Anatolia) -Kaysariya (Turkey) -Latokia (Syria) -Damask-Gaza (Palestine) -Ismailia (Egypt) -Cairo-Sawaish-Yonbuk-Jeddah-Mecca. This route has been chosen by many Central Asian pilgrims.

It is reported that Muhammad Hakim Khan, who returned from Hajj through Iran, traveled in the direction of Baghdad-Hamadon-RishtTehran-Rud-Bistom-Sabzavor-Nishapur-TusMashhad-Sarakhs-Maymana-Andhuy-Bukhara. Hence, the information in the work allows us to imagine the roads and conditions in the two directions in the northern and central directions connecting Central Asia and Mecca.

It is necessary to dwell on the difficulties of the long journey described in the play. The author's impressions of the natural obstacles encountered on the roads in the northern direction, in particular the drought and the hot weather, provide a very rich data. For example, Muhammadhakim Tora writes that he traveled through the desert for 10 days to cross the road between Orenburg and Astrakhan. "We have made a sandy weed, as painful as space, and the waters of which pass through the throat and intestines in agony. Having seen this landscape of the wasteland.. I had lost a thousand hopes for my sweet soul and agreed to die."

On the main road, too, natural obstacles such as hot desert weather, drought, sandstorms in the deserts also posed a great threat to the lives of passengers. Evidence of this can be 
found in the work of Muhammadhakim Khan Tora on the pilgrimage. He calls the desert road from Damascus to Baghdad a "butcher's steppe." The author writes that many animals of the caravan could not cope with the drought and heat on this desert road, which lasted for 30 days.

Again, artificial barriers on the road do not go noticed by the author. The author also explains how dangerous the Shia-Sunni conflict is for pilgrims. On his return from Hajj, he described the incidents on the roads from Baghdad to Iranian cities in the following sentences: “... We did it in Hamadan province. It is a very big and very prosperous city. At that time, I had not yet taken off my Roman (Turkish (G.T.)) clothes, which angered the Shiite Iranians. I turned to the province. Therefore when I left this city I reluctantly left the road to Tehran and turned the direction of the route to the Kurdistan region where the entire population is a sect of Shafi'i "

He even mentions that he always traveled in fear of this danger on the roads passing through all of Iran. For example, when he travels to the Iranian capital, he wears an "Iranian red dress," and even, as was the custom at the time, "pulls his hair forward like an Iranian youth." In his words, in this view, "no one could know that he was a Sunni." But even though he took such measures, in a caravanserai in Sabzavor (a city in Khorasan), his owner, Muhammadhakim Khan, realized that Tora was a Sunni Central Asian and raised a forest. The author barely escaped from this place with the help of his companions.

Muhammadhakim Khan Tora narrated another incident on the Shia-Sunni issue, which can provide interesting information for a full analysis of the dangers of pilgrimage. If the author escaped danger by secretly posing as a Shiite in Iran, he forced to remove his mask in front of the Turkmen in the country and use all his power to prove that he is Sunni. In particular, on his way back from Hajj, he fall into the hands of Turkmen robbers on a mountain road in Chinoran on the road between Sabzavor and Tus in Iran. Then Muhammadhakim Khan Tora tried to prove that he was a Sunni by saying, "I am a pilgrim, and I am among them because I am afraid of the Shiites." It is clear from this evidence that Shia-Sunni ideological conflicts during this period were considered one of the most serious threats to the pilgrimage of Central Asian Muslims.

\section{The Work Contains The Following Sentences:}

"When we came to Anapa, the governor of Sinab, Hoja Hasan Pasha, also visited Anapa. He was the Emir of Hajj twice. I asked him to write a letter of recitation so that I could go to Rome. The old man said, "Sir, the situation in Istanbul is very dangerous now, and no ships have come from there yet." Only the ship from Sinob is sailing. My lord Sultan Mahmud, that is, the Greek sultan, was outraged by the New Cherik community and the Bektashis, and executed seventy thousand of them in one day. At the same time, there is no good in going to Rumania. Sir, be patient for a few days, and soon the road will be open. Then it will be better for them to go. So I got a Tazkira letter" for Sinob, that is, a "guide," and said goodbye to the old man. He called the captain of the ship and allowed me to leave him only after he had handed over the poor man to him." It turns out that often some passengers used certain documents-permits in order to travel safely on international roads. Such permits, called names such as notes, letters, travel orders, tickets or passports, are issued only by celebrities. And 
even at times when political turmoil prevailed, it was only offered to act in ways that were considered relatively safer. Because the purpose of getting it was actually to get to the destination safely.

According to the author, in the XIX century, such a permit to move on the territory of Russia could be obtained only from the emperor or the governor of any region. Because when he himself asked the mayor of the town of Shamay, near Omsk, for this document, he said that he could not give it, that he could only get it from the governor in Omsk. The governor was not in the city when the author arrived in Omsk. "According to this picture, when there is no husband, the wife asks about the affairs of the country," he said. So I had also asked the governor's wife for permission.... On the fourth day, she stamped my permit, held it in my hand, and allowed me to leave." This means that in Russia, instead of the governor of the region, sometimes his wife was also able to issue stamped permits to passengers.

The author also mentions that it took four days for regional governors in Omsk to obtain such a permit, and that the king himself had to send a letter to the capital to obtain such a permit, which took more than six months. This meant that most pilgrims tried to get permission from the governor of the province because it was easier to get permission than from the king.

According to the play, Muhammadhakimkhan had the opportunity to meet with the Russian king Alexander II, who visited the city of Orenburg in 1824-25 during his visit to Tora. The king sent him a letter saying, "Wherever this Muhammadhakimkhan goes to Russia, his honor will be restored!" Muhammadhakimkhan Tora was honorably taken aboard with the written permission of Alexander II to continue his voyage on the Volga River.

In the course of acquaintance with the work, we witness that the author obtained permission from the king's deputies in every town or village stopped in the territory of Russia along the way and continued on his way with him. For example, he received permission from the royal office in the village of Dushenskaya on the Kaban River, and in Anapa from the governor of Sinob (a town on the nose of Injeburun in northern Turkey), Hodja Hasan Pasha, a "tazkira letter" for the Sinob road to cross the Ottoman border. On his way back from Hajj, he wrote a letter for the Damascus-Baghdad route from King Muhammadsalih, the governor of Damascus, to Hassan, the ruler of Baghdad, and from King Hassan, the governor of Sanandaj, the capital of Kurdistan Province in Iran. .

It is known that on March 13, 1844, the ambassador sent by the Shah of Iran Muhammad Shah left Tehran for Bukhara to visit Amir Nasrullah. The caravan of the Iranian ambassador will be joined by the ambassador of Bukhara Said Khalilkhoja and ten or fifteen pilgrims from Bukhara returning from Hajj. The following sentences written in the play about the memories of the Iranian ambassador's visit also confirm the above:

"We handed over the letters of Mr. Osaf udDawla (Governor-General of Khurasan Province) to Nafasbek and Turobbek Taka, the elders of the Turkmen tribes in Sarakhs, asking us to pass through this area with honor and respect. They swam freely through the gushing water and went to deliver the letter to its owners. The next day, when the sun went down, both elders arrived indifferently". 
From this information, it can be seen that pilgrims who went on or returned from the Hajj often preferred to continue their journey by joining the caravans of dignitaries, ambassadors who had "tazkira" or official letters for security reasons. It is also understandable that those who have letters and "tazkiras" have been able to almost avoid the artificial barriers that can be created by the government or forces within their sphere of influence in the territories of other states. It should be noted that usually wherever a passenger or pilgrim arrives, their permits were signed by the local authorities of that place. The information was given by Muhammadhakim Khan Tora about this confirms our opinion. He entered the royal court in Kuban province and signed his permit confirming that he was here.

Muhammadhakimkhan Tora's pilgrimage allowed him to keep abreast of industrial and technical innovations in the developed countries at that time, as well as changes in the cultural and educational spheres. This caused the author's attitude towards these news to be reflected in his travel memories. In particular, the play provides information about the new schools that are emerging in Asian countries on the example of the description of the place for the education of adolescents, called "Qasri ayn", which the author saw in Cairo. The structure of this school, the spacious and bright rooms, the teaching process, the uniforms specially introduced for the students, did not go noticed by the author. The play also teaches secular knowledge such as medicine, arithmetic, calligraphy, etiquette, lessons in Turkish, Persian, and Arabic. It was also mentioned about the shipment. Muhammadhakimkhan Tora was amazed to see the place where the most talented young people were sent to Europe to study science. He also spoke about the fact that in almost all cities of the Russian Empire there are such places for the education of children, and that their provision is carried out at the expense of the state treasury.

\section{CONCLUSION}

In short, Muhammadhakimkhan Tora's Mutahab at Tavarikh is a very important source on the pilgrimage from Central Asia to Mecca in the 19th century. Its most important source value is that it is written on the basis of events that the author has seen and experienced with his own eyes, and the events are described in sequence and in detail. By analyzing the information about the pilgrimages of the peoples of Central Asia in the work, it is possible to study the political, socio-economic processes in the Central Asian khanates in the XIX century, the history of international relations and communication routes (especially the main routes).

It also provides an in-depth analysis of the history of the Central Asian khanates' international relations with Russia, the Ottoman Empire, Iran, Afghanistan, the history of the Bukhara, Khiva and Kokand khanates, and the history of Shiite-Sunni relations. As a result of the analysis of historical data in the work, it is possible to study the impact of pilgrimage on the development of culture of different peoples, the history of their customs and traditions, as well as information about some historical figures who lived in that period.

\section{REFERENCES}

1. Muhammadhakimxon Tora. Muntahab at-tavori. Translated from Persian-Tajik. 
author of introduction, comments and indicators Sh.Vakhidov. T. 2010. p.7.

2. Axmedov B.A. Historical and geographical literature of Central Asia XVI-XVIII centuries. (Pismennye pamyatniki), T .: Fan, 1985. p. 126.

3. Muhammadhakimxon Tora. Muntahab at-tavorix. pp.590-623.

4. Travelogue of Bukhara (on diplomatic relations between Amir Nasrullo and Muhammad Shah Qajar. 1844). Translated from Persian by Ismail Bekjan. Tashkent. 2007. p.26.

5. Djuraeva, S. (2020). Classification Of Pilgrimages In Sherobod Oasis. The American Journal of Interdisciplinary Innovations and Research, 2(11), 17-20.

6. Djuraeva, S. (2020). Shrines Of The Karshi Oasis. The American Journal of Applied sciences, 2(11), 12-15.

7. Khamidova, M. (2017). Studying of Uzbekistan's architectural monuments at the end of XIX-early XX centuries (on the basis of local archive sources). European Journal of Humanities and Social Sciences, (2), 14-16.

8. Djuraeva, S. (2020). Activities Of Sheikh And Servants In Pilgrimages. The American Journal of Social Science and Education Innovations, 2(11), 11-15. 